ISSN: 2685-4252 (Online) and ISSN: 2685-0540 (Print)

Vol. 3, No. 3, November 2021, pp: $125-141$

DOI: https://doi.org/10.31849/utamax.v3i3.7280

\title{
Technology Exposure: Its Relationship to the Study Habits and Academic Performance of Students
}

\author{
Ronilo G. Berondo ${ }^{1}$, \& Jayson A. Dela Fuente ${ }^{2}$ \\ ${ }^{1}$ Capiz State University-Tapaz Satellite College, Capiz, Philippines \\ ${ }^{2}$ Northern Negros State College of Science and Technology, Sagay City, Philippines \\ delafuentejayson89@gmail.com
}

\begin{abstract}
Received : 2021-07-11
Revised : 2021-10-12

Accepted : 2021-10-13
\end{abstract}

ARTICLE HISTORY

\section{KEYWORDS}

Academic performance

Relationship

Secondary school's students

Study habits

Technology eexposure

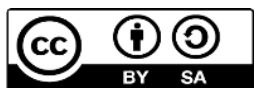

\begin{abstract}
The 21st century emphasizes the role of technology in different facets of life, especially in the educational system, as it serves as a platform for teachers and students in the delivery of effective teaching and learning process. In this perspective, descriptive-correlational research determines the level of technology exposure and its relationship to the study and academic performance in Social Studies subject of the one hundred seventy-four (174) students who were randomly chosen from a total population of six hundred eighty-eight (688) during the School Year 2018-2019 in the three selected public secondary schools in the district of Tapaz West, Schools Division of Capiz, Philippines. The data were gathered using a standardized survey questionnaire and analyzed using descriptive statistics: mean, percentage, frequency count, and standard deviation. For the inferential statistics: ttest, analysis of variance, and Pearson $r$ correlation at 0.05 level of significance through the aid of the SPSS software version 27. The study's significant findings revealed that exposure to technology significantly relates to students' study habits. At the same time, it does not significantly relate to their academic performance in Social Studies subjects. The findings suggest that school administrators, parents, teachers, and other stakeholders should ensure that students are properly guided to the right technology platforms to support learning and improve their study habits towards excellent academic achievement.
\end{abstract}

\section{Introduction}

The 21st century emphasizes the role of technology in different facets of life, especially in the educational system. It serves as a platform for teachers and students to deliver effective teaching and learning processes (Dela Fuente, 2021; Aktürk, 2020). Technology advancement and development has widespread its significant role through Information and Communications Technology (ICT). However, the use of technology in the education sector still focuses on the dissemination of information. Ortiz, et.al, (2011) stressed that in the so-called "digital age," it is necessary to help students become adept and technology savvy on the pedagogical and technical use of ICT to advance their academic career.

Schools as an academic institutions are mandated to educate students holistically with different necessary skills for survival. In a complex and competitive era wherein things are run by technology, schools should shift to the demands of the present time, as suggested by
$\mathrm{Fu}$, (2013), to prepare students for a more sophisticated digital society. The Social Studies subject as one of the subjects taught by the teachers in the secondary schools has been regarded as the essential attribute for liberal education. Bruhwiler and Blatchford (2011) believed that a good education in social science has become imperative because of its practical application to other disciplines, and it widens student's perspectives on society. However, to sustain its momentum as a gamechanger field of discipline there should be intensive training for teachers by integrating technology to effectively deliver quality Social Studies subject learning to the students (Halem, 2011).

Apparently, students are exposed to technology at home and school due to different technological platforms like social media. The school administrators and teachers should design a curriculum in which technology is appropriately integrated (Dela Fuente, 2021; Tondeur, 2018); and take advantage of the technology to deliver quality and effective teaching for students' active engagement and positive academic 
performance (Lee, 2009). Technology has been a compulsory field as in the 21 st-century skills that students should possess to become adept in the new trends of education. Akturk and Ozturk (2019) underscored the significant role of technology as they engage its practical application that enhances and foster their cognitive development. Therefore, students should master the appropriate techniques to process, transfer, and acquire information brought about by different technological platforms in compliance with the legal and ethical norms of handling data for privacy (Mikis, 2002). This research was supported by Ghamravi (2013) that technology education can provide opportunities for students not only in the academe but also in the workplace. Seemingly, Dela Fuente (2019) stressed that parents are essential factors as they play a vital role in a student's career choice and good study habits to perform and excel academically in school and give pride to the family. In support of the role of parents, they provide the necessary tool like technology for their students to advance in school learning activities (Stock \& Fishman, 2010). The statement was supported by Halem (2011) that technology has a positive effect on students' cognitive development. Technology has been integrated by teachers in the teaching process as it can stimulate students' interest and active engagement in class discussions and to have better learning (Dela Fuente, 2021; Lee, 2009).

Individual differences in students' academic performance have been linked to intelligence, personality, and study habits. Arias and Walker (2004) highlighted that when students have good study habits portray a pre and post-academic achievement. Congruently, Tezci (2011) indicated that students in public schools have good study habits in Social Studies, thus leading them to perform academically. Ertmer and Ottenbreit-Leftwich (2010) affirmed such findings that students would have well even outstanding academic achievements if they developed good study habits. Therefore, the student's academic success of the students in school is greatly affected by their ability to have good study habits that can stimulate their positive engagement for meaningful learning activities (Ghavifekr et al., 2014). Several factors identified on students' study habits preference was gender groups. Wilson (2011) asserted a statistically significant difference between males and females in terms of visual, auditory, and tactile individual learning study habits. Based on the study conducted by Singapore and Caucasian undergraduate students in Michigan it was reported that Asian female students have a strong preference for auditory and visual learning (Aslan \& Zhu, 2015; Alharthi, 2020). Research on study habits has an enormous significance concerning establishing the context of applying student's understanding for positive learning and excellent academic achievement (Barrett \& Toma, 2013).Ll

The given overview inspired the researchers to investigate and gather empirical evidence to determine the extent of technology exposure and its relationship to students' habits and students' academic performance through a descriptive correlation study. The results will shed light on the appropriate intervention to attain students' academic on the proper intervention.

\subsection{Objectives of the Study}

The study sought to determine the extent of technology exposure and its relationship to students' study habits and academic performance in Social Studies subjects. Specifically, it aims to answer the following questions:

1) What is the level of study habits of the respondents according to their profile in terms of age, sex, educational attainment of parents, household size, and monthly income?

2) İs there a significant relationship between students' technology exposure and study habits based on their profile in terms of age, sex, parents' educational attainment, household size, and monthly income?

3) Is there a significant relationship between technology exposure to study habits and students' academic performance in Social Studies subjects?

\subsection{Null Hypotheses}

Ho1. There is no significant difference in students' technology exposure and study habits when grouped according to age, sex, parents' educational attainment, household size, and monthly income.

Ho2. There is no significant relationship between technology exposure, study skills, and academic performance of secondary school students in Social Studies subjects.

\subsection{Conceptual Framework}

About figure 1, it shows how the study was conducted. The student's profile as to age, sex, educational attainment of parents, household size and monthly income, the respondent's exposure to technology, and the study habits are considered the inputs to determine the student's academic performance in Social Studies subject. 


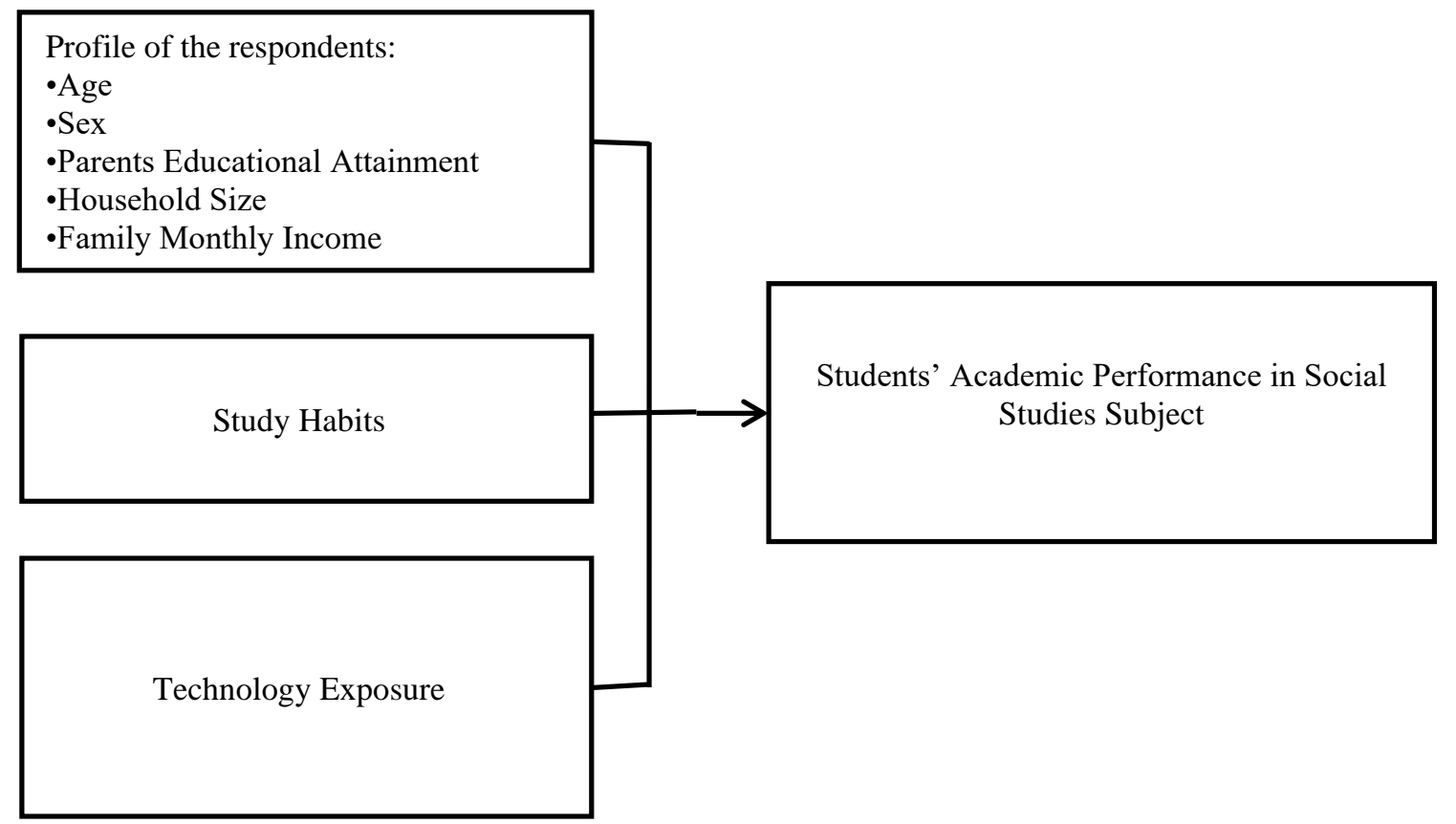

Figure 1. Schematic Diagram Showing the Framework of the Study

The conceptual model shows that ICT exposure, study skills of secondary high school students, and its relationship to their academic performance are assumed to be affected by personal-related variables, such as age, sex, parents' educational attainment, household size, and monthly household income. The student's academic performance in Social Studies is assumed to be related to ICT exposure and study skills.

\section{Methods}

\subsection{Research Design}

The descriptive-correlation research design was used in this investigation. It seemed essential and appropriate to determine the extent of students' technology exposure to their study habits and academic performance.

\subsection{Respondents of the Study}

Using Slovin's formula, the identified respondents of the study are the one hundred seventy-four (174) students who were randomly chosen from a total population of six hundred eighty-eight (688) during the School Year 2018-2019. Moreover, the researchers decided that the study will be conducted to the three (3) nearest big schools out of five (5) public secondary schools in the district of Tapaz West, Schools Division of Capiz, the Philippines, due to its geographical location, which is far from each other. Moreover, the selected schools have been considered top-performing schools for the past five consecutive years. The chosen secondary schools are the Candelaria $(n=64)$, San Nicolas $(n=49)$, and Tapaz $(n=61)$ National High Schools.

Table 1. Samples of the Respondents

\begin{tabular}{lccc}
\hline School & N & n & \% \\
\hline Candelaria NHS & 256 & 64 & 37.20 \\
San Nicolas NHS & 191 & 49 & 27.90 \\
Tapaz NHS & 241 & 61 & 34.90 \\
Total & 688 & 174 & 100.00 \\
\hline
\end{tabular}

*NHS (National High School) 


\subsection{Research Instrument}

The researchers employed a standardized survey questionnaire which is consists of three parts. Part I is the profile of the respondents in terms of age, sex, parents' educational attainment, household size, and monthly income. Part II is the scale composed of statement indicators to capture the level of technology exposure of the respondents. The response choices were: (5) always, (4) often, (3) sometimes, (2) rarely, and (1) not at all. In comparison, Part III is the study habits inventory comprised of 14 statements. Moreover, the average grade of the students was taken from the office of the school's principal for validation and accuracy of the gathered data as to the students' academic achievement.

\subsection{Data Gathering Procedure}

Before the data gathering started, a permit was secured from the Schools Division Superintendent and School Heads/Principals of the three high schools. After the license was granted, coordination was done with the secondary school principals for the schedule of the data gathering. The researcher did data gathering, and the researcher did retrieval was done by the researcher. The researchers sent a letter to the division superintendent and school principal asking permission to conduct the study and to access the respondents. Teachers were then given informed consent and explained to them the purpose of their participation and assured that their responses would be treated with the utmost confidentiality. To ensure one hundred percent of data retrieval, the researchers administer the survey questionnaire to the respondents. Then it was analyzed using the appropriate statistical software, Statistical Package of the Social Sciences (SPSS) version 27.

\subsection{Statistical Tools}

To provide precise analysis and interpretation of the gathered data, the researchers utilized descriptive and inferential statistics. For descriptive analysis, frequency count, mean, standard deviation, and the percentage was used. To determine the relationship between the extent of technology exposure, study habits, and academic performance of the respondents in Social Studies subject, Pearson's r Product Moment Coefficient of Correlation was used t-test and the Analysis of Variance (ANOVA) for the independent samples. The Results interpreted at a $0.05 \%$ level of significance..

\subsection{Scoring Interpretation}

The following variables were used in the study to categorize the academic performance of students in Social Studies subject guided with the standard scaling of General Weighted Average (GWA) and its verbal interpretation by the Department of Education.

General Weighted Average

\begin{tabular}{|c|c|c|}
\hline & Scale & Verbal Description \\
\hline & $90-95$ & Outstanding \\
\hline & $86-89$ & Very Satisfactory \\
\hline & $80-85$ & Satisfactory \\
\hline & $75-79$ & Fair \\
\hline \multicolumn{3}{|c|}{ General Weighted Average } \\
\hline & Scale & Verbal Description \\
\hline & $4.20-5.00$ & Very High \\
\hline & $3.40-4.19$ & High \\
\hline & $2.60-3.39$ & Average \\
\hline & $1.80-2.59$ & Low \\
\hline & $1.00-1.79$ & Vey Low \\
\hline \multicolumn{3}{|c|}{ Study Habits } \\
\hline Scale & \multicolumn{2}{|c|}{ Verbal Interpretation } \\
\hline $2.57-3.00$ & \multicolumn{2}{|r|}{ Very Good } \\
\hline $2.23-2.56$ & \multicolumn{2}{|r|}{ Good } \\
\hline $1.89-2.22$ & \multicolumn{2}{|r|}{ Average } \\
\hline Below 1.89 & \multicolumn{2}{|r|}{ Poor } \\
\hline
\end{tabular}




\section{Results}

The first two tables clearly reflect the distribution of the respondents as to age and according to sex with a total of 174 identified respondents by the researchers which was participated in the study.

Table 2. Distribution of the Respondents according to Age

\begin{tabular}{lll}
\hline Age & f & \% \\
\hline \multirow{2}{*}{ 14 and below } & 9 & 5.17 \\
15 & 79 & 45.40 \\
16 and above & 86 & 49.43 \\
\hline Total & $\mathbf{1 7 4}$ & $\mathbf{1 0 0 . 0 0}$ \\
\hline
\end{tabular}

Table 3. Distribution of the Respondents according to Sex.

\begin{tabular}{lll}
\hline Sex & $\mathbf{f}$ & \% \\
\hline Male & 88 & 50.57 \\
Female & 86 & 49.43 \\
\hline Total & $\mathbf{1 7 4}$ & $\mathbf{1 0 0 . 0 0}$ \\
\hline
\end{tabular}

Table 2 indicates that most of the respondents are ages 16 and above that comprises almost 49.43\% (86 sample) of the total population. This was followed by 15 years which are the 79 samples $(45.40 \%)$. Whilst, 14 years old and below got the lowest percentage (5.17) about 9 of the total respondents in terms of age. Moreover, Table 3 shows that there is a small gap in terms of the number of samples between male and female respondents with 88 and 86 respectively. The figures further convey that the respondents are male $(50.57 \%)$ dominated than female $(49.43 \%)$ in terms of sex.

Table 4. Respondents' Parents Educational Attainment (Father)

\begin{tabular}{lll}
\hline Educational Attainment & f & \% \\
\hline Elementary Level & 7 & 4.02 \\
Elementary Graduate & 9 & 5.17 \\
High School Level & 9 & 5.17 \\
High School Graduate & 97 & 55.75 \\
Bachelor's Degree & 8 & 4.60 \\
BS with Master's Units & 10 & 5.75 \\
Master's Degree & 14 & 8.05 \\
Master's Degree with Doctorate & 10 & 5.75 \\
Units & 10 & 5.75 \\
Doctorate Degree & & \\
\hline Total & $\mathbf{1 7 4}$ & $\mathbf{1 0 0 . 0 0}$ \\
\hline
\end{tabular}

Table 5. Respondents' Parents Educational Attainment (Mother)

\begin{tabular}{lll}
\hline Educational Attainment & f & $\mathbf{1 \%}$ \\
\hline Elementary Level & 7 & 4.02 \\
Elementary Graduate & 3 & 1.72 \\
High School Level & 21 & 12.07 \\
High School Graduate & 79 & 45.40 \\
Bachelor's Degree & 18 & 10.34 \\
BS with Master's Units & 10 & 5.75 \\
Master's Degree & 25 & 14.37 \\
Master's Degree with Doctoral & 5 & 2.87 \\
Units & 6 & 3.45 \\
Doctoral Degree & &
\end{tabular}

\begin{tabular}{lcc}
\hline Total & 174 & 100.00 \\
\hline
\end{tabular}

As reflected in Table 4, the majority of $55.75 \%$ of the respondents' father was a high school graduate and $8.05 \%$ are master's degree holder. The same percentage of about $5.75 \%$ for a doctorate, master's degree with doctorate units and bachelor's degree with master's units respectively. Moreover, the same percentage $(5.17 \%)$ for high school level and elementary graduate. Furthermore, 8 or about $4.60 \%$ are bachelor degree holder and $7(4.02 \%)$ are elementary level. In terms of the educational attainment of the respondents 'mother as highlighted in Table 5, it was found out that majority are high school graduate with 79 samples that comprises of about $45.40 \%$ of the total population. Moreover, 25 $(14.37 \%)$ are a master degree holder, $21(12.07 \%)$ are high school level, $10(5.75 \%)$ are BS with master's degree units, 7 (4.02\%) are elementary level, 6 (3.45\%) doctorate holder; $5(2.87 \%)$ are master's degree with doctorate units and $3(1.72 \%)$ are elementary graduate.

Table 6. Respondents Household Size

\begin{tabular}{lll}
\hline Household Size & f & \% \\
\hline $4-8$ & 121 & 69.54 \\
& & \\
& & \\
9 and above & 34 & 19.54 \\
$1-3$ & 19 & 10.92 \\
& & \\
\hline Total & $\mathbf{1 7 4}$ & $\mathbf{1 0 0 . 0 0}$ \\
\hline
\end{tabular}


Table 7. Respondents Family Monthly Income

\begin{tabular}{lll}
\hline Monthly Income & f & \% \\
\hline Php10,000 and below & 59 & 33.91 \\
& & \\
Php10,001-15,000 & 59 & 33.91 \\
Php15,001 and above & 56 & 32.18 \\
\hline Total & $\mathbf{1 7 4}$ & $\mathbf{1 0 0 . 0 0}$ \\
\hline
\end{tabular}

In terms of household size of the respondents, Table 6 revealed that the 121 which is about $69.54 \%$ of the total population have 4-8 family members, 34 (19.54\%) have 9 and above members while the $(10.92 \%)$ have $1-3$ household members. On the other hand, Table 7 presents the monthly income of the respondents' parents in which Php10,000 and below and Php10,001-15,000 gained the same results of 59 (33.91) of the total respondents while only $56(32.18 \%)$ of the parents has an income which is above Php15,001. The computed mean of Php17,390 indicates that the respondents' households were living above the national poverty threshold of Php14,000 for the family of six according to the Philippines' National Economic and Development Agency (NEDA).

Table 8. Level of the Respondents Technology Exposure.

\begin{tabular}{lll}
\hline Technology Exposure & f & \% \\
\hline & & \\
Very High & 54 & 31.03 \\
High & 43 & 24.71 \\
Average & 32 & 18.39 \\
Low & 23 & 13.22 \\
Very Low & 22 & 12.64 \\
Grand Mean = 3.90 High & & \\
& & \\
\hline Total & $\mathbf{1 7 4}$ & $\mathbf{1 0 0 . 0 0}$ \\
\hline
\end{tabular}

Based on Table 8, the level of respondents technology exposure shows that $54(31.03 \%)$ of the samples have Very High exposure. The 43 (24.71\%) are
High exposed, 32 (18.39\%) are Average, 23 (13.22\%) are Low, while 22 of them are at a Very Low exposure to technology. The computed mean of 3.90 indicates that the respondents have a High level of exposure to technology in general.

Table 9. Level of Respondents Study Habits

\begin{tabular}{lll}
\hline Study habits & f & $\%$ \\
\hline Very Good & 91 & 52.30 \\
Good & 83 & 47.70 \\
Grand Mean = 87.48 Very High & & \\
\hline Total & $\mathbf{1 7 4}$ & $\mathbf{1 0 0 . 0 0}$ \\
\hline
\end{tabular}

Table 10. Level of the Respondents Academic Performance in Social Studies Subject

\begin{tabular}{lll}
\hline Study Habits & f & \% \\
\hline & & \\
Outstanding & 16 & 9.20 \\
& & \\
Very Satisfactory & 63 & 36.21 \\
Satisfactory & 95 & 54.60 \\
Grand Mean $=85.11$ & Satisfactory & \\
& & \\
\hline Total & $\mathbf{1 7 4}$ & $\mathbf{1 0 0 . 0 0}$ \\
\hline
\end{tabular}

As to the study of the respondents, Table 9 highlighted that almost $91(52.30 \%)$ have a Very Good study habits. Whilst $83(47.70 \%)$ of the samples are at a Good level. In general, the level of the respondents' study habits is Very High with the grand mean of 87.48. Moreover, as reflected in Table 10, it indicates that in general the students' academic performance in Social Studies subject is in the Satisfactory level with a grand mean of 85.11 . There are $95(54.60 \%)$ who are in the Satisfactory and $63(36.21 \%)$ in the Very Satisfactory respectively.

Table 11. Difference in Respondents Technology Exposure according to Age

\begin{tabular}{llllll}
\hline Sources of Variation & $\begin{array}{l}\text { Sum of } \\
\text { Squares }\end{array}$ & Df & $\begin{array}{l}\text { Mean } \\
\text { Squares }\end{array}$ & $f$-value & $\begin{array}{l}\boldsymbol{p} \text { - } \\
\text { value }\end{array}$ \\
\hline Between Groups & 1.657 & 2 & 0.829 & $0.887 \mathrm{~ns}$ & 0.414 \\
Within Groups & 159.699 & 171 & 0.934 & & \\
\hline Total & 161.356 & 173 & & &
\end{tabular}

*ns (Not Significant) 
Table 12. Differences in Respondents Technology Exposure according to Sex

\begin{tabular}{lccccc}
\hline Compared Groups & Df & M & Sd & t-value & $\boldsymbol{p}$-value \\
\hline Male & & 3.29 & 0.95 & & \\
Female & 172 & 2.97 & 0.96 & & \\
\hline
\end{tabular}

*Significant at $0.05 \%$ Level

In reference to Table 11, the results of the analysis using t-test revealed that there is no significant difference in the technology exposure of the respondents when group according to age with the value of $(f=0.887 ; p=0.414)$. Therefore, the null hypothesis is thereby Accepted. This implied further that regardless of age the respondents have the same perceived technology exposure. Moreover, Table 12 presents that based on the result of the t-test as to whether there is a significant difference in the technology exposure of the respondents when group according to sex, the findings indicated that there is a significant difference in the technology exposure when respondents are group according to sex as shown by the $t$-value of 2.209 and 0.029 level of probability respectively. Thus, the findings revealed that there is positive statistical evidence to Reject the null hypothesis. Furthermore, the results conclude that the technology exposure of the respondents was directly affected by their sex. The results affirm the findings of Aslan and Zhu (2015), Eickelmann and Vennemann (2017) that the male and female students differ significantly as to their exposure to technology.

Table 13. Differences in Respondents Technology Exposure according to Parents Educational Attainment (Father)

\begin{tabular}{llllll}
\hline Sources of Variation & $\begin{array}{l}\text { Sum of } \\
\text { Squares }\end{array}$ & Df & $\begin{array}{l}\text { Mean } \\
\text { Squares }\end{array}$ & $\boldsymbol{f}$-value & $\boldsymbol{p}$-value \\
\hline Between Groups & 36.630 & 8 & 4.579 & & \\
Within Groups & 124.726 & 165 & 0.756 & & \\
Total & 161.356 & 173 & & & \\
\hline ** Highly Significant at $0.05 \%$ Level & & &
\end{tabular}

Table 14. Differences in Respondents Technology Exposure according to Parents Educational Attainment (Mother)

\begin{tabular}{|c|c|c|c|c|c|}
\hline Sources of Variation & $\begin{array}{l}\text { Sum of } \\
\text { Squares }\end{array}$ & Df & $\begin{array}{l}\text { Mean } \\
\text { Squares }\end{array}$ & $f$-value & $p$-value \\
\hline Between Groups & 20.041 & 8 & 2.505 & \multirow{3}{*}{$2.925 * *$} & \multirow{3}{*}{0.000} \\
\hline Within Groups & 141.315 & 165 & 0.856 & & \\
\hline Total & 161.356 & 173 & & & \\
\hline
\end{tabular}


Table 13 indicates that based on the result of the analysis using the f-test, there is a significant difference in the respondents' technology exposure according to the educational attainment of their father with the $f$ value of .925 and a $p$-value of 0.000 respectively. Therefore, the null hypothesis which states that there is no significant difference in the technology exposure of the students when classified according to the highest educational attainment of their father is thereby Rejected. The findings affirm to Padasas (2012) that the technology exposure of the students significantly differs when grouped according to their father's educational attainment. Moreover, as shown in Table 14, the findings indicate that there is a significant difference in the technology exposure when respondents were grouped according to the educational attainment of their mother $(f=2.925 ; p=0.000)$. Therefore, the null hypothesis which states that there is no significant difference in the students' technology exposure when they grouped according to the educational attainment of the respondents" mother is also thereby Rejected.

Table 15. Differences in Respondents Technology Exposure according to Household Size

\begin{tabular}{llllll}
\hline Sources of Variation & $\begin{array}{l}\text { Sum of } \\
\text { Squares }\end{array}$ & Df & $\begin{array}{l}\text { Mean } \\
\text { Squares }\end{array}$ & $\boldsymbol{f}$-value & $\boldsymbol{p}$-value \\
\hline Between Groups & 0.707 & 2 & 0.353 & $0.376 \mathrm{~ns}$ & 0.678 \\
Within Groups & 160.649 & 171 & 0.939 & & \\
Total & 161.356 & 173 & & & \\
\hline
\end{tabular}

*ns (Not Significant)

Table 16. Differences in Respondents Technology Exposure according to Family Monthly Income

\begin{tabular}{|c|c|c|c|c|c|}
\hline Sources of Variation & $\begin{array}{l}\text { Sum of } \\
\text { Squares }\end{array}$ & Df & $\begin{array}{l}\text { Mean } \\
\text { Squares }\end{array}$ & $f$-value & p-value \\
\hline Between Groups & 21.851 & 2 & 10.125 & & \\
\hline Within Groups & 139.505 & 171 & 0.816 & $13.392 * *$ & 0.000 \\
\hline Total & 161.356 & 173 & & & \\
\hline
\end{tabular}

** Highly Significant

As shown in Table 15, based on the results of the analysis on the differences of technology exposure when respondents were grouped according to household size using the f-test, the findings indicate that there is no significant difference in the level of students technology exposure $(f=0.376 ; p>.05)$. This was the basis for Accepting the null hypothesis that there is no significant difference in technology exposure when students are grouped according to household size. On the other hand, the result of the analysis using the f-test, Table 16 indicates that there is a significant difference in technology exposure when respondents are grouped according to family monthly income $(f=13.392$; $p=0.000)$. Therefore, the null hypothesis which states that there is no significant difference in technology exposure of the students according to family monthly income is thereby Rejected. The findings implied that the higher the family's monthly income of the respondents the higher was their exposure to technology. The results affirm the study of Ghavifekr et al. (2015) and Eickelmann and Vennemann (2017) that there is a significant relationship between technology exposure and household monthly income. 
Table 17. Differences in Respondents Study Habits according to Age

\begin{tabular}{llllll}
\hline $\begin{array}{l}\text { Sources of } \\
\text { Variation }\end{array}$ & $\begin{array}{l}\text { Sum of } \\
\text { Squares }\end{array}$ & Df & $\begin{array}{l}\text { Mean } \\
\text { Squares }\end{array}$ & f-value & p-value \\
\hline Between Groups & 0.149 & 2 & 0.074 & & \\
Within Groups & 15.957 & 171 & 0.93 & & \\
\hline Total & 16.106 & 173 & & & \\
\hline *ns (Not Significant) & & & & & \\
\end{tabular}

Table 18. Differences in Respondents Study Habits according to Sex

\begin{tabular}{llllll}
\hline Compared Groups & Df & $\begin{array}{l}\text { Mean } \\
\text { Squares }\end{array}$ & $\begin{array}{l}\text { Standard } \\
\text { Deviation }\end{array}$ & t-value & p-value \\
\hline Male & 172 & 2.60 & 0.49 & $3.440 \mathrm{~ns}$ & 0.001 \\
Female & & 2.35 & 0.48 & & \\
\hline ** Highly Significant & & & & &
\end{tabular}

The reflected findings in Table 17 indicates that there is no significant difference in the respondents' study habits when group according to age. This was the basis for Accepting the null hypothesis that there are no significant differences in the study habits when classified according to age $(f=0.797 ; p=0.452)$. The results suggest that the student study skills are similar regardless of age. The findings indicated in Table 18 shows that there is a significant difference in the study habits in Social Studies subject when respondents were classified according to sex given the $t$-value of 3.440 and the level of probability which is less than 0.001 the null hypothesis is thereby Rejected. This affirms the findings of Aslan and Zhu (2015), Eickelmann and Vennemann

(2017).

Table 19. Differences in Respondents Study Habits according to

Parents' Educational Attainment (Father)

\begin{tabular}{llclll}
\hline Sources of Variation & $\begin{array}{l}\text { Sum of } \\
\text { Squares }\end{array}$ & Df & $\begin{array}{l}\text { Mean } \\
\text { Squares }\end{array}$ & $\boldsymbol{f}$-value & $\boldsymbol{p}$-value \\
\hline Between Groups & 1.521 & 8 & 0.190 & $2.151 *$ & 0.034 \\
Within Groups & 14.585 & 165 & 0.088 & & \\
Total & 16.106 & 173 & & & \\
\hline
\end{tabular}

*Significant 
Table 20. Differences in Respondents Study Habits according to Parents' Educational Attainment (Mother)

\begin{tabular}{llllll}
\hline Sources of Variation & $\begin{array}{l}\text { Sum of } \\
\text { Squares }\end{array}$ & Df & $\begin{array}{l}\text { Mean } \\
\text { Squares }\end{array}$ & $\boldsymbol{f}$-value & $\boldsymbol{p}$-value \\
\hline Between Groups & 0.552 & 8 & 0.069 & $0.733 \mathrm{~ns}$ & 0.663 \\
Within Groups & 15.554 & 165 & 0.094 & \\
Total & 16.106 & 173 & & \\
*ns (Not Significant) & & &
\end{tabular}

The results of the analysis using the f-test as indicated in Tale 19, there is a significant difference in the study habits of the respondents in term of the educational attainment of their father $(f=2.151$; $p=0.034)$. Therefore, the null hypothesis which states that there is no significant difference in the study habits when the respondents were classified according to the educational attainment of their father is thereby Rejected. It was found out that respondents whose father have a higher level of education had better study habits than those with a lower level of education. Moreover, Table 20 indicates that there is no significant difference in the study habits in Social Studies subject when respondents were classified according to the educational attainment of their mother. This was the basis for Accepting the null hypothesis which states that there is no significant difference in the study habits of the respondents when classified according to the educational attainment of their mother $(f=0.733$; $p=0.663$ ). The results suggest that students study habits is the similar regardless of the highest educational attainment of their mother.

Table 21. Differences in Respondents Study Habits according to Household Size

\begin{tabular}{llllll}
\hline Sources of Variation & $\begin{array}{l}\text { Sum of } \\
\text { Squares }\end{array}$ & Df & $\begin{array}{l}\text { Mean } \\
\text { Squares }\end{array}$ & $\boldsymbol{f}$-value & $\boldsymbol{p}$-value \\
\hline Between Groups & 0.504 & 2 & 0.252 & $2.763 \mathrm{~ns}$ & 0.066 \\
Within Groups & 15.602 & 171 & 0.091 & \\
Total & 16.106 & 173 & & & \\
\hline
\end{tabular}

*ns (Not Significant)

Table 22. Differences in Respondents Study Habits according to Family Monthly Income

\begin{tabular}{llllll}
\hline Sources of Variation & $\begin{array}{l}\text { Sum of } \\
\text { Squares }\end{array}$ & Df & $\begin{array}{l}\text { Mean } \\
\text { Squares }\end{array}$ & $f$-values & $p$-value \\
\hline Between Groups & 0.016 & 2 & 0.008 & $0.085 \mathrm{~ns}$ & 0.919 \\
Within Groups & 16.090 & 171 & 0.094 & \\
Total & 16.106 & 173 & & & \\
\hline *ns (Not Significant) & &
\end{tabular}

*ns (Not Significant) 
As shown in Table 21, the result of analysis on the difference in the study habits in Social Studies subject when the respondents were classified according to household size $(f=2.763 ; p=0.066)$ the findings indicates that there is no significant difference. This was the basis for Accepting the null hypothesis which states that there is no significant difference in the study habits in Social Studies subject when the respondents are grouped according to household size. Whilst, Table 22 revealed that when the respondents were classified according to the family's monthly income the results of the f-test convey that there is no significant difference $(f=0.085$; $p=0.919)$. The result leads to the Acceptance of the null hypothesis stating that there is no significant difference in the study habits in Social Studies subject when the respondents are grouped according to household monthly income. This means that the study skills in Social Studies subject is similar regardless of the family's monthly income of the respondents.

Table 23. Differences in Respondents Academic Performance in Social Studies Subject According to Age

\begin{tabular}{llllll}
\hline Sources of Variation & $\begin{array}{l}\text { Sum of } \\
\text { Squares }\end{array}$ & Df & $\begin{array}{l}\text { Mean } \\
\text { Squares }\end{array}$ & $\boldsymbol{f}$-values & $p$-value \\
\hline Between Groups & 15.882 & 2 & 7.941 & $1.021 \mathrm{~ns}$ & 0.362 \\
Within Groups & 1329.819 & 171 & 7.777 & \\
\hline Total & 1345.701 & 173 & & \\
\hline *ns (Not Significant) & & & &
\end{tabular}

Table 24. Differences in Respondents Academic Performance in Social Studies Subject According to Sex

\begin{tabular}{llllll}
\hline Compared Groups & Df & $\begin{array}{l}\text { Mean } \\
\text { Squares }\end{array}$ & $\begin{array}{l}\text { Standard } \\
\text { Deviation }\end{array}$ & t-Values & p-Value \\
\hline Male & 172 & 85.06 & 2.94 & $-0.272 \mathrm{~ns}$ & 0.782 \\
Female & & 2.35 & 0.48 & & \\
\hline *ns (Not Significant) & & & &
\end{tabular}

Table 23 revealed that there was no significant difference in the academic performance of the respondents in the Social Studies subject when they were classified according to age as shown by the computed $f$-value of 1.021 . This means that regardless of age the respondent academic performance towards the subject remains the same. When students are grouped according to sex, the result of the t-test revealed that there is no significant difference in the performance of male and female respondents $(t=-0272$; $p=782$ ). The results lead to the Acceptance of the null hypothesis stating that there is no significant difference in the academic performance of the respondents when they were classified according to sex as shown in Table 24. 
Table 25. Differences in Respondents Academic Performance in Social Studies Subject According to Parents' Educational Attainment (Father)

\begin{tabular}{llllll}
\hline Sources of Variation & $\begin{array}{l}\text { Sum of } \\
\text { Squares }\end{array}$ & Df & $\begin{array}{l}\text { Mean } \\
\text { Squares }\end{array}$ & $\boldsymbol{f}$-value & $\boldsymbol{p}$-value \\
\hline Between Groups & 23.190 & 8 & 2.829 & $0.362 \mathrm{~ns}$ & 0.939 \\
Within Groups & 1322.512 & 165 & 8.015 & \\
\hline Total & 1345.701 & 173 & & \\
*ns (Not Significant) & & &
\end{tabular}

Table 26. Differences in Respondents Academic Performance in Social Studies Subject According to Parents' Educational Attainment (Mother)

\begin{tabular}{llllll}
\hline Sources of Variation & $\begin{array}{l}\text { Sum of } \\
\text { Squares }\end{array}$ & Df & $\begin{array}{l}\text { Mean } \\
\text { Squares }\end{array}$ & $\boldsymbol{f}$-value & $\boldsymbol{p}$-value \\
\hline Between Groups & 61,486 & 8 & 7.686 & $0.987 \mathrm{~ns}$ & 0.448 \\
Within Groups & 1284.215 & 165 & 7.783 & \\
\hline Total & 135.701 & 173 & & \\
\hline *ns (Not Significant) & & &
\end{tabular}

The f-test results under Table 25 shows no significant difference in the academic performance of the respondents in the Social Studies subject when they were classified according to the educational attainment of their father $(f=0.362 ; p=0.939)$. This was the basis for Accepting the null hypothesis which states that there is no significant difference in respondents' academic performance. In Table 26, when students were classified according to the educational attainment of their mother, the results shows that there is no significant difference in the academic performance of the respondents $(f=-$ 0987; $p=0.448)$. The result serves as the basis to Accept the null hypothesis stating that there is no significant difference in the academic performance of the respondents when they were classified according to the educational attainment of their mother.

Table 27. Differences in Respondents Academic Performance in Social Studies Subject According to Household Size

\begin{tabular}{llllll}
\hline Sources of Variation & $\begin{array}{l}\text { Sum of } \\
\text { Squares }\end{array}$ & Df & $\begin{array}{l}\text { Mean } \\
\text { Squares }\end{array}$ & $\boldsymbol{f}$-value & $\boldsymbol{p}$-value \\
\hline Between Groups & 5.661 & 2 & 2.830 & $0.361 \mathrm{~ns}$ & 0.697 \\
Within Groups & 1340.040 & 171 & 7.836 & \\
\hline Total & 1345.701 & 173 & & \\
\hline *ns (Not Significant) & & &
\end{tabular}


Table 28. Differences in Respondents Academic Performance in Social Studies suject Subject According to Family Monthly Income

\begin{tabular}{llclll}
\hline Sources of Variation & $\begin{array}{l}\text { Sum of } \\
\text { Squares }\end{array}$ & Df & $\begin{array}{l}\text { Mean } \\
\text { Squares }\end{array}$ & $f$-value & $p$-value \\
\hline Between Groups & 11.848 & 2 & 5.924 & $0.759 \mathrm{~ns}$ & 0.469 \\
Within Groups & 1333.853 & 171 & 7.800 & & \\
\hline Total & 1345.701 & 173 & & & \\
\hline *ns (Not Significant) & & & &
\end{tabular}

As reflected in Table 27 based on the analysis on the difference in the performance of the respondents in Social Studies subject using f-test when grouped according to household size $(f=-0987 ; p=0.448)$ the result shows that there are no significant differences in the respondents' academic performance in Social Studies subject. Thus, the null hypothesis stating that there is no significant difference in the performance of the respondents when they were classified according to their household size is thereby Accepted. On the other hand, Table 28 shows with the given value of $(f=0.759$; $p=0.469$ ) it was found out family income has no significant difference in the students' academic performance in the Social Studies subject.

Table 29. Relationship on the Extent of Technology Exposure to

Study Habits of the Respondents in Social Studies Subject

\begin{tabular}{|c|c|c|c|c|}
\hline \multirow[t]{2}{*}{ Variable } & \multicolumn{2}{|c|}{ Technology Exposure } & \multicolumn{2}{|c|}{ Study habits } \\
\hline & & r prob & $\boldsymbol{R}$ & r prob \\
\hline Technology Exposure & 1.00 & 0.000 & $0.193 *$ & 0.011 \\
\hline Study habits & $0.193^{*}$ & 0.011 & 1.00 & 0.000 \\
\hline
\end{tabular}

The results of the analysis of the relationship on the extent of technology exposure and study habits in Social Studies subject as reflected in Table 29 with the given $r$ value of 0.193 and the p-value .011 indicates the presence of a positive moderate correlation between the two variables. Therefore, the null hypothesis stating the absence of a relationship between the extent of technology exposure and study habits is thereby Rejected. This implies that the higher technology exposure directly affects the respondents' study habits.

Table 30. Relationship on the Extent of Technology Exposure to Academic Performance of the Respondents in Social Studies Subject

\begin{tabular}{|c|c|c|c|c|}
\hline \multirow[t]{2}{*}{ Variable } & \multicolumn{2}{|c|}{$\begin{array}{l}\text { Extent of Technology } \\
\text { Exposure }\end{array}$} & \multicolumn{2}{|c|}{$\begin{array}{l}\text { Academic Performance in } \\
\text { Social Studies subject }\end{array}$} \\
\hline & & r prob & $R$ & r prob \\
\hline $\begin{array}{l}\text { Academic Performance in } \\
\text { Social Studies subject }\end{array}$ & $-0.015 \mathrm{~ns}$ & 0.845 & 1.00 & 0.000 \\
\hline
\end{tabular}

*ns (Not Significant) 
The finding indicates in the Table 30 revealed that there is no significant relationship between the extent of technology exposure and the respondents" academic performance in Social Studies subject ( $r=-015$; $p=0.845)$. The results lead to the Acceptance of the null hypothesis stating that there is no significant relationship between the extent of technology exposure and the students' academic performance in Social Studies subject.

Table 31. Relationship between Study Habits and Academic Performance of the Respondents in Social Studies Subject

\begin{tabular}{llllc}
\hline \multirow{2}{*}{ Variable } & \multicolumn{2}{c}{$\begin{array}{c}\text { Extent of Technology } \\
\text { Exposure }\end{array}$} & \multicolumn{2}{c}{$\begin{array}{l}\text { Performance in Social } \\
\text { Studies subject }\end{array}$} \\
\cline { 2 - 5 } & \multicolumn{2}{r}{ r prob } & $\boldsymbol{R}$ & $\boldsymbol{r}$ prob \\
\hline $\begin{array}{l}\text { Study habits in Social Studies } \\
\text { subject }\end{array}$ & 1.00 & 0.000 & $0.027 \mathrm{~ns}$ & 0.726 \\
$\begin{array}{l}\text { Academic Performance in } \\
\text { Social Studies subject }\end{array}$ & $0.027 \mathrm{~ns}$ & 0.726 & 1.00 & 0.000 \\
\hline *ns (Not Significant) & & & &
\end{tabular}

The result of the analysis on the relationship between study habits and academic performance in Social Studies subject as indicated in Table 31 with the given r-value of 0.027 and a p-value of 0.726 it was found out that there is no significant relationship between the two variables. Therefore, the null hypothesis stating that there is no significant relationship between study habits and academic performance in Social Studies subject is thereby Accepted. It implied that academic performance in the Social Studies subject of the respondents is not significantly affected by study habits.

\section{Discussion}

Improving the quality of education is a complex and challenging process that involves intensive and concrete action planning and decision-making of academic stakeholders (Dela Fuente, 2021). In the results, the majority of the respondents were 15 years old and below of which male-dominated with fathers who were high school graduates and mothers who are at least high school level of education which belong to a household with 4-8 members, and had a monthly income of 15,000 and below. Padasas (2012) believed that the technology exposure of the students significantly differs when grouped according to their parents' educational attainment.

The respondents have a very high exposure to technology which implies that these students must have been provided with opportunities to be exposed to the different technological platforms to improve further and support the education process. Students' exposure has a significant implication of having developed excellent study skills in Social Studies, which attract their interest towards the subject (Stock \& Fishman, 2010). Their exposure to technology was significantly affected by their sex, educational attainment, the monthly of their parents, and household size. The study skills of the respondents were greatly influenced by their sex, the educational attainment of their parents. Furthermore, the results conclude that the technology exposure of the respondents was directly affected by their sex. This was affirmed by Aslan and Zhu (2015), Eickelmann and Vennemann (2017) that the male and female students differ significantly as to their exposure to technology. Interestingly, their age, the educational attainment of their mothers, their household size, and their monthly income does not bear any influence. It was inferred that the study skills of the respondents are a personal attribute that cannot be interfered with by any external factors and forces. The study skills are innate to the students in which they are the ones who can discover their own and unique study skills (Ghavifekr et al., 2014; Eickelmann \& Vennemann, 2017).

The performance of the respondents in the Social Studies subject was found to be not significant as to their age, sex, educational attainment and monthly income of parents, and household size. However, there was a significant relationship between technology exposure and the study skills of the respondents in the Social Studies subject. Vividly, technology exposure and the study skills of the respondents were not significantly related to the respondent's academic performance in the Social Studies subject (Halem, 2011). Notably, the satisfactory performance level of the students in the Social Studies subject sheds light on areas that need to be improved to attain the ultimate success in education with the aid of different educational technologies. 
It was inferred that parents educated on the vital role of technology in their students' academic performance have a strong influence on students' technology exposure. Moreover, parents are actively engaged and devote time to provide guidance and supervision on the proper use of educational technologies. Students from households with a high monthly income have significantly higher exposure to technology which implies that their parents can provide for their technological needs.

Apparently, students' academic performance in Social Studies is consistent regardless of their age, sex, parents' educational attainment, household size, and monthly household income. High exposure to technology can significantly improve students' study skills of students in Social Studies subjects. Students have high regard and perception of the significant role of technology in their academic success (Akturk \& Ozturk, 2019). Therefore imperative that students should be provided with opportunities to expose themselves to different technologies for it helps enhance their cognitive abilities. The learning can be enriched with the aid of educational technology in delivering the quality teaching and learning process (Dela Fuente \& Biñas, 2020). Decisions of policy-makers on how to improve the quality of education should anchor on the assessment of the existing procedures and practices that includes the expansion and application of relevant technology to provide meaningful learning experiences to students in the context of the technological age of the educational system.

\section{Conclusion}

Technology is essential nowadays for it to become partners of teachers in the delivery of quality and effective teaching, thus providing interactive engagement to students. The teachers in the academic should take advantage of the use of different technological platforms to attract students' attention towards the subject. The present study revealed that students have excellent study habits in Social Studies topics. It implies that students developed an interest in the subject as they were exposed themselves to technology as a source of their academic learning activities. The respondents have a perception that they had high technology exposure implying that these students must have been provided with opportunities to be exposed to the different educational technology platforms. Hence, they have excellent study skills in Social Studies, which further implied that they had developed excellent study skills and their likelihood of the issues. Male students significantly have higher exposure to different technologies. They have better study habits in the Social Studies subject with the significant preference of which their parents strongly influence better study skills. The satisfactory level of performance in Social Studies of the respondents highlighted areas needing interventions to improve students' performance towards the subject. Perhaps, if parents are well-educated, they can better understand the advantages and disadvantages of higher exposure to different technologies. Thus they provided strict parental guidance and supervision to their children regarding the proper and appropriate use of technologies. Students coming from a household with a high monthly income significantly have higher exposure to technology of which is very understandable that their family can provide the needs of their children, including their need for technology, through different educational platforms for their studies. Students' satisfactory academic performance in Social Studies subject should be elevated to a higher level or even towards an outstanding or excellent grade. Thus, intervention should be done to address this phenomenon. Moreover, male students have significantly higher exposure to technology which was inferred that this group of students has a greater chance to excel academically in Social Studies subject. The academic institution should look at it as a gender bias issue that should be addressed by providing equal opportunities to different gender preferences as to their exposure to technology for the academic endeavor.

\section{Recommendations}

Based on the present study, the following are recommended to strengthen the contribution and impact of technology exposures to students' academic achievement.

1) The Department of Education (DepEd), through its management personnel, may develop academic plans to regulate students' technology exposure through strong collaboration and partnership with stakeholders.

2) The school management may provide and expose students to different technological platforms for academic purposes to enhance their study habits in Social Studies but also in other disciplines.

3) The teacher may design/develop interactive learning activities in Social Studies by integrating technology to attract students' interest in the subject.

4) Other researchers may replicate the present study to validate the results further using different variables, settings, and context.

\section{References}

Akturk, A. O., \& Ozturk, H. S. (2019). Teachers' TPACK levels and students' self-efficacy as predictors of students' academic achievement. International Journal of Research in Education and Science (IJRES), 5(1), 283-294. 
Aktürk, A.O. (2020). Prediction of problematic Internet usage of university students by their attachment styles. International Journal of Education in Mathematics, Science and Technology, 8(4), 318329. https://doi.org/10.46328/ijemst.v8i4.1170

Alharthi, M. (2020). Students' Attitudes toward the Use of Technology in Online Courses. International Journal of Technology in Education, 3(1), 14-23.

Arias, J.J. \& Walker, D.M. (2004). Additional evidence on the relationship between class size and students performance. Journal of Economics education, $35(4)$, https://doi.org/10.3200/JECE.35.4.311-329n

Aslan, A., \& Zhu, C. (2015). Pre-Service teachers' perceptions of ICT integration in teacher education in Turkey. Turkish Online Journal of Educational Technology-TOJET, 14(3), 97-110.

Barrett, N. \& Toma, E.F. (2013). Reward or punishment? Class size and Teacher quality. Economics of Education Review, 35(2) 41-52. https://doi.org/10.1016/j.econedurev.2013.03.001

Bruhwiler, C. \& Blatchford, D (2011). Effects of class size and adaptive teaching competency on classroom processes and academic outcome. Learning and Instruction, 21(1), 95-108. https://doi.org/10.1016/j.learninstruc.2009.11.004

David, A. (2005). "Study Skills for Dyslexic Students, California: SAGE Publication. Inc.

Dela Fuente, J.A. \& Biñas, L.C. (2020). Teacher's competence in Information and Communications Technology (ICT) as an Educational Tool in Teaching: An Empirical Analysis for Program Intervention. Journal of Research in Education, Science and Technology, 5(2), 61-76.

Dela Fuente, J.A. (2019). Driving Forces of Students' Choice in Specializing Science: A Science Education Context in the Philippines Perspective. The Normal Lights, 13(2), 225-250.

Dela Fuente, J.A. (2021). Contributing factors to the performance of pre-service physical science teachers in the Licensure Examination for Teachers (LET) in the Philippines. Journal of Educational Research in Developing Areas, 2(2), 141-152.

https://doi.org/10.47434/JEREDA/2.2.2021.141

Dela Fuente, J.A. (2021). Facebook Messenger as an educational platform to scaffold deaf students' conceptual understanding in environmental science subject: A single group quasiexperimental study. International Journal of
Education, $\quad$ 14(1),

19-29.

https://doi:10.17509/ije.v14i1.31386.

Dela Fuente, J.A. (2021). Implementing inclusive education in the Philippines. College teacher experiences with deaf students. Issues in Educational Research, 31(1), 94-110.

Eickelmann, B., \& Vennemann, M. (2017). Teachers 'attitudes and beliefs regarding ICT in teaching and learning in European countries. European Educational Research Journal, 16(6), 733-761. https://doi.org/10.1177\%2F1474904117725899

Ertmer, P. A., \& Ottenbreit-Leftwich, A. T. (2010). Teacher technology change: How knowledge, confidence, beliefs, and culture intersect. Journal of Research on Technology in Education, 42(3), 255-284.

https://doi.org/10.1080/15391523.2010.10782551

Fu, J. (2013). Complexity of ICT in education: A critical literature review and its implications. International Journal of Education and Development Using ICT, 9(1), 112-125.

Ghamrawi, N. (2013). The relationship between the leadership styles of public school principals' and their attitudes towards ICT versus the level of ICT use by their teachers. Open Journal of Leadership, 2(1), 11-20. http://dx.doi.org/10.4236/oj1.2013.21002

Ghavifekr, S., Razak, A. Z. A., Ghani, M. F. A., Ran, N. Y., Meixi, Y., \& Tengyue, Z. (2014). ICT integration in education: Incorporation for teaching \& learning improvement. Malaysian Online Journal of Educational Technology, 2(2), 24-45.

Halem, K.R. (2011). Children's choices and strategies in video games. Computus in Human Behavior, 27(1), https://doi.org/10.1016/j.chb.2010.10.001

Lee, S.M. (2009). Computer Use and Academic Development in Secondary Schools. Computers in the Schools, 26(30), 224-235. https://doi.org/10.1080/07380560903095204

Mikis, M.K. (2003). The situation of informatics and Task for Development. UJ Pedagagiaiszemle, 211(6) 35-49.

Ortiz, R.W. (2011). Families and Home Computer Use: Exploring Parent Perceptions of the Importance of Current Technology. Urban Education, 46(2), 202-215. https://doi.org/10.1177/0042085910377433 
Stock, E \& Fishman, R. (2010). The Not-so-Simple Debate on Home computers and Achievement. Education Week, 20(7) 24-26.

Summak, M. S., \& Samancioğlu, M. (2011). Assessment of technology integration in vocational education and training schools. International Journal of Education and Development Using ICT, 7(1), 68-85.

Tezci, E. (2011). Factors that influence pre-service teachers' ICT usage in education. European Journal of Teacher Education, 34(4), 483-499. https://doi.org/10.1080/02619768.2011.587116

Tondeur, J. (2018). Enhancing future teachers' competencies for technology integration in education: Turning theory into practice. International Journal of Media, Technology and Lifelong Learning, 14(2), 216-224. 